\title{
Revealing the alkaline characteristic evolution of bauxite residue under biomass fermentation
}

by Wu, C., Li, C., Jiang, J., Hartley, W., Kong, X., Wu, Y. and Xue, $\mathrm{S}$.

Copyright, publisher and additional information: .This is the authors' accepted manuscript. The published version is available via Springerlink.

Please refer to any applicable terms of use of the publisher.

DOI: https://doi.org/10.1007/s11368-019-02482-5 
1 Revealing the alkaline characteristic evolution of bauxite residue

2 under biomass fermentation

3

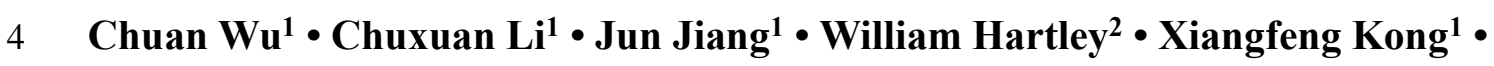

5 Yujun $\mathrm{Wu}^{1} \cdot$ Shengguo Xue

6

$7{ }^{1}$ School of Metallurgy and Environment, Central South University, Changsha,

$8 \quad 410083$, China

$9 \quad{ }^{2}$ Crop and Environment Sciences Department Harper Adams University Newport UK

10

$11 \bowtie$ Jun Jiang

12 junjiang@csu.edu.cn

$13 \square$ Shengguo Xue

14 sgxue@csu.edu.cn 


\section{Abstract}

Purpose: Biomass fermentation has been proposed as a simple and economical strategy to alleviate the high alkalinity of bauxite residue. This study investigates the neutralization of bauxite residue following the application of biomass as an alkali modifier by natural fermentation.

Materials and methods: Fresh bauxite residue samples were collected from Pingguo refinery (Aluminum Corporation of China). Samples were treated with straw mulching (SC), straw mixing (SM), bagasse mulching (BC), and bagasse mixing (BM), respectively. Treatments were analyzed for $\mathrm{pH}, \mathrm{EC}$, metal cations and soluble alkali $\left(\mathrm{OH}^{-}, \mathrm{Al}(\mathrm{OH})_{4}{ }^{-}\right.$and $\left.\mathrm{CO}_{3}{ }^{2-}\right)$. The mineral phase and $\mathrm{Na}$ speciation were analyzed by $\mathrm{X}-$ ray diffraction (XRD) and near-edge X-ray absorption fine structure (Na-XANES).

Results and discussion: Optimum application rate for either straw or bagasse was $20 \%$ $(\mathrm{w} / \mathrm{w})$, reducing leachate $\mathrm{pH}$ from 10.26 to 8.56 . During biomass transformation, the alkaline mineral grossular was completely dissolved, whilst calcite and cancrinite were dissolved to a lesser degree. No treatment changed the spatial distribution of $\mathrm{Na}^{+}$, but the basic anions $\left(\mathrm{OH}^{-}, \mathrm{CO}_{3}{ }^{2-}\right.$ and $\left.\mathrm{Al}(\mathrm{OH})_{4}^{-}\right)$were significantly reduced.

Conclusions: Following treatment application, soluble alkali in the residues was significantly reduced whilst the alkaline minerals were slightly dissolved. This was determined as the main cause for the decrease in residue $\mathrm{pH}$.

Keywords Bauxite residue $\bullet$ Biomass $\bullet$ Neutralization $\bullet$ Soluble alkali $\bullet$ Transformation 


\section{Introduction}

Bauxite residue is a high-alkaline solid waste produced by digestion of bauxite with caustic soda during the alumina production process (Xue et al. 2016a; Kong et al. 2017a). This process produces a high residue ratio, with a ton of alumina product producing 1-2.0 tons of residue. This has lead to the greatest emissions of any nonferrous metal smelting industry around the world (Xue et al. 2016b; Xu et al. 2010; Zhu et al. 2017; Santini and Fey 2018). In 2018, the global stock of bauxite residue reached 4.6 billion tons and is still increasing with a rate of approximately 170 million tons annually (Xue et al. 2019a; Zhu et al. 2016; Kong et al. 2018). Bauxite residue pH can reach 10-13, with the corresponding leachate as high as 12-14 (Power et al. 2011; Li et al. 2018; Santini and Fey 2015). The primary alkaline minerals associated with bauxite residue include andradite $\left(\mathrm{Ca}_{3}\left(\mathrm{Fe}_{0.87} \mathrm{Al}_{0.13}\right)_{2}\left(\mathrm{SiO}_{4}\right)_{1.65}(\mathrm{OH})_{5.4}\right), \quad$ cancrinite $\left(\mathrm{Na}_{8} \mathrm{Al}_{6} \mathrm{Si}_{6} \mathrm{O}_{24}\left(\mathrm{CO}_{3}\right)\left(\mathrm{H}_{2} \mathrm{O}\right)_{2}\right)$, calcite $\left(\mathrm{CaCO}_{3}\right)$ and grossular $\left(\mathrm{Ca}_{3} \mathrm{Al}_{2} \mathrm{Si}_{3} \mathrm{O}_{12}\right)$. These highly buffered minerals have the ability to continuously dissolve and release basic anions $\left(\mathrm{OH}^{-}, \mathrm{CO}_{3}{ }^{2-}\right.$ and $\left.\mathrm{Al}(\mathrm{OH})_{4}^{-}\right)(\mathrm{Kong}$ et al. 2017b). As a consequence, problems such as crystalline bloom, alkaline aggregate reaction and steel corrosion will occur, which restricts its recycling and results in an extremely low utilization ratio (less than 10\%) (Santini et al. 2011; Huang et al. 2016). Therefore, regulation of its alkalinity is key to its recycling potential (Klauber et al. 2011).

Current research has largely focused on removal of its alkalinity, including gypsum transformation, seawater neutralization, carbon dioxide $\left(\mathrm{CO}_{2}\right)$ sequestration and acid neutralization (Burke et al. 2013; Courtney and Kirwan 2012; Barbhuiya et al. 2011). Application of gypsum has been widely used for the restoration of bauxite residue disposal areas (Courtney and Timpson 2005; Xue et al. 2019b). This process, relies on $\mathrm{Ca}^{2+}$ from the gypsum to form carbonate precipitates with alkaline substances in the residue, thus inhibiting the dissolution of alkaline minerals thereby reducing $\mathrm{pH}$; it is however a long-term restorative process. Seawater treatment is similar to that of gypsum (Burke et al. 2013; Xue et al. 2019b; Babu and Reddy 2011; Renforth et al. 2012). $\mathrm{Ca}^{2+}$ and $\mathrm{Mg}^{2+}$ in seawater are introduced into the bauxite residue to reduce $\mathrm{pH}$, but the presence of $\mathrm{Na}^{+}$will destroy the physical and chemical structure of the bauxite 

年

residue. Also, the alumina plant needs to be close to the coast, signifying a geographical restriction (Clark et al. 2015; Mayes et al. 2006; Menzies et al. 2004). Acid interaction can effectively remove most of the basic compounds, but dissolved calcium and aluminum in solution produce considerable quantities of liquid waste contributing to secondary pollution (Burke et al. 2013; Khaitan et al. 2009; Yang et al. 2016; Couperthwaite et al.2013). $\mathrm{CO}_{2}$ sequestration involves reactions between $\mathrm{CO}_{2}$ and hydroxide to form carbonate and bicarbonate, but it also promotes the dissolution of chemical bonded alkali such as tri-calcium aluminate (TCA) (Sahu et al. 2010; Han et al. 2017; Jones et al. 2006). In addition, $\mathrm{CO}_{2}$ sequestration requires a high pressure atmosphere to maintain sufficient interaction between reactants, which increases operation cost (Smith 2009; Khaitan and Dzombak 2009).

Biomass transformation of bauxite residue is mainly attributed to microbial fermentation processes and production of metabolites to reduce alkalinity and improve its physical and chemical properties (Courtney and Harrington 2012; Jones et al 2012; You et al. 2019). It is emerging as a promising in-situ remediation method for bauxite residue disposal areas (Khaitan et al. 2010). Ren et al. (2017) discovered that the pH of bauxite residue decreased from 10.60 to 8.96 following addition of $20 \%(\mathrm{w} / \mathrm{w})$ vinegar or furfural residues (Ren et al. 2017). The effect of furfural residue on $\mathrm{pH}$ reduction was greater than with vinegar residue. Furfural residue is more acidic and contains approximately $5 \%$ surface functional groups including $-\mathrm{NH}_{2},-\mathrm{OH}$ and other free acids, which promote a faster $\mathrm{pH}$ drop. Courtney and Harrington (2012) demonstrated that addition of mushroom compost biomass improved the residues physicochemical properties and reduced its alkalinity. Although $\mathrm{pH}$ reduction from biomass treatments is inferior when compared to other methods, it is more appealing to use accessible biomass as a mild alkali modifier. 
This work investigates the effect of straw and bagasse biomass on bauxite residue alkalinity neutralization following biological fermentation. The effects of biomass dosage and application methods on the neutralization effect of bauxite residue alkalinity are also investigated. Development of $\mathrm{pH}$ following natural fermentation processes was assessed and optimized.

\section{Materials and methods}

\subsection{Sample collection and processing}

Fresh bauxite residue samples were collected from Pingguo refinery (Aluminum Corporation of China), in south-west China (Latitude $23^{\circ} 18^{\prime 2} 28.68^{\prime \prime} \mathrm{N}$, Longitude $\left.107^{\circ} 31^{\prime} 8.15^{\prime \prime} \mathrm{E}\right)$. Three subsamples were collected with a distance of 5 meters from each sampling point. Samples were placed into polyethylene bags and brought back to the laboratory. Samples were firstly air-dried at $65^{\circ} \mathrm{C}$ for $72 \mathrm{~h}$, and subsequently sieved $<2 \mathrm{~mm}$. As local biomass recycling materials, rice straw and bagasse were selected as treatments. They were allowed to air-dry naturally, pulverized and then sieved to $<2$ $\mathrm{mm}$ before use.

\subsection{Biomass investigations}

Bauxite residue (50 g) was weighed into plastic containers. The residues were then treated as follows: straw mulching (SC), straw mixing (SM), bagasse mulching (BC) and bagasse mixing (BM). Rice straw and bagasse were added to each treatment as 2 , $4,6,8,10,20,30$ and $40 \%$ weight/weight. Hereafter BR refers to the un-treated bauxite residue. Milli-Q water was then added until a solid-liquid ratio 1:5 was achieved. After applying the treatments, all samples were placed on a shaker at $120 \mathrm{rpm}\left(25^{\circ} \mathrm{C}\right)$ and shaken for $30 \mathrm{~d}$. Each treatment was carried out in triplicate. Samples were then centrifuged at $4000 \mathrm{r} / \mathrm{min}$ for $20 \mathrm{~min}$ and the suspensions analyzed for $\mathrm{pH}, \mathrm{EC}$ and soluble cations. Transformed residual solids were washed twice with Milli-Q water then over-dried at $65{ }^{\circ} \mathrm{C}$. Subsequently, the dried solids were crushed in a mortar to disaggregate and sieved to retain the $<2 \mathrm{~mm}$ fraction. 


\subsection{Sample characterization}

$\mathrm{pH}$ was immediately determined in all experiments using a PHS-3C and the concentration of $\mathrm{OH}^{-}$was calculated from $\mathrm{pH}$ data. $\mathrm{CO}_{3}{ }^{2-}$ was analyzed by indicatorneutralization titration using $0.002 \mathrm{M} \mathrm{H}_{2} \mathrm{SO}_{4}$ (Kirwan et al. 2013). Determination of element concentrations ( $\mathrm{Al}, \mathrm{Ca}, \mathrm{Na}, \mathrm{Mg}$ and $\mathrm{K}$ ) was carried out using Inductively Coupled Plasma Auto Emission Spectrometry (Optima 5300 DV; PerkinElmer, Waltham, MA, USA) and the $\mathrm{Al}(\mathrm{OH})_{4}{ }^{-}$was calculated from the $\mathrm{Al}$ concentration.

Phase compositions of dried bauxite residue samples were analysed on a Bruker D8 discover 2500 X-ray diffraction (XRD). XRD patterns were collected from 10 to $80^{\circ}$ at a $0.04^{\circ} 2 \theta$ step size and a $1^{\circ} 2 \theta \mathrm{min}^{-1}$ scan rate. The PANalytical analysis package was used to identify and quantify phases from XRD data. The amount of amorphous material in the sample was fitted and calculated by Jade v.7 software.

Near-edge X-ray absorption fine structure (Na-XANES) and soft X-ray scanning transmission microscopy (STXM) of Na were performed on the BL08U1A beamline of the Shanghai Synchrotron Radiation Facility (SSRF). Samples were uniformly prepared on a conductor copper substrate that fixed on the sample holder through a ceramic sheet. The substrate was connected to the current amplifier through a wire. Standard spectra of sodium were collected from $\mathrm{Na}_{2} \mathrm{CO}_{3}$ and cancrinite. Sodium K-edge spectra of the photon energy in the range of 1065-1095 eV were collected by a double crystal monochromator consisting of beryllium (100 reflections). The mode of total yield detection was used with a $1 \mathrm{~s}$ counting time and $0.1 \mathrm{eV}$ step. Athena 1.2.11 was used to normalize and average the NEXAFS spectra. The distribution of $\mathrm{Na}$ in samples was analyzed by STXM.

\section{Results and discussion}

\section{$3.1 \mathrm{pH}$}

$\mathrm{pH}$ of the supernatants from the various treatments are displayed in Table 1. Following mulching with $2 \%$ straw, $\mathrm{pH}$ decreased from 10.26 to 9.97 . Leachate $\mathrm{pH}$ decreased continuously with increasing straw volume. At $20 \%$ straw, $\mathrm{pH}$ decreased to 8.76. Following mulching with straw at $40 \%, \mathrm{pH}$ decreased to 9.79 . At $2 \%$ straw mixing, 
supernatant $\mathrm{pH}$ was reduced to 10.08 . At $20 \%$ straw mixing, $\mathrm{pH}$ decreased to 8.99 . The effect of bagasse mulching and mixing on $\mathrm{pH}$ transformation was similar to that of straw. At $2 \%$ mulching with bagasse, leachate $\mathrm{pH}$ decreased to 9.96 . When the dosage of bagasse increased to $20 \%$, $\mathrm{pH}$ decreased to 8.56 . Mixing with $20 \%$ bagasse, decreased $\mathrm{pH}$ to 8.75 , indicating a lower $\mathrm{pH}$ decrease as compared to that of mulching with bagasse. Based on the above results, both straw and bagasse will reduce residue $\mathrm{pH}$, but mulching was slight better than that of mixing. An optimized dosage of straw or bagasse-based biomass was estimated to be $20 \%$, which could decrease leachate $\mathrm{pH}$ to 8.56 .

In the current work, it was interesting to find that the drop in $\mathrm{pH}$ of treated bauxite residues exhibited a volcano-type trend, which presented a minimum $\mathrm{pH}$ with a $20 \%$ biomass dosage. When the biomass ratio increased to $30 \%$ or $40 \%$, filtrate $\mathrm{pH}$ showed an increase as compared to that of bauxite residue treated with $20 \%$ biomass. According to previous reports, (Ren et al. 2017; David et al. 2006; Patel et al. 2006) factors such as fermentation temperature, substrate concentration, $\mathrm{pH}$ and even nitrogen source, may play important roles in biomass fermentation to produce acidic species. In fact, optimum acid production temperature, substrate concentration, $\mathrm{pH}$ and nitrogen source for biomass fermentation vary greatly. For straw and bagasse fermentation in the current work, the drop in $\mathrm{pH}$ for the $30 \%$ or $40 \%$ biomass may be attributed to the above analysis. The straw or bagasse provides the carbon source for microbial growth and reproduction, a low substrate concentration cannot meet the growth requirements of microorganisms, whilst too high a substrate concentration would inhibit the growth of microorganisms (Klinke et al. 2004; Mondala et al. 2015) Meanwhile, increased biomass dosages would lead to a disruption in the balance for anaerobic and aerobic fermentation in the system, which may affect acid production performance and result in a decline in $\mathrm{pH}$ compared to bauxite residue with a lower biomass ratio.

\subsection{Mineralogy}

XRD was applied to analyze mineral phases (Fig. 1). From quantitative calculations of the various phases (Table 2) with different biomass treatment, we concluded that alkaline minerals from bauxite residue were significantly transformed 
during the investigation. The primary alkaline minerals from BR were indexed to andradite $\left(\mathrm{Ca}_{3}\left(\mathrm{Fe}_{0.87} \mathrm{Al}_{0.13}\right)_{2}\left(\mathrm{SiO}_{4}\right)_{1.65}(\mathrm{OH})_{5.4}\right)$, cancrinite $\left(\mathrm{Na}_{8} \mathrm{Al}_{6} \mathrm{Si}_{6} \mathrm{O}_{24}\left(\mathrm{CO}_{3}\right)\left(\mathrm{H}_{2} \mathrm{O}\right)_{2}\right)$, calcite $\left(\mathrm{CaCO}_{3}\right)$, and grossular $\left(\mathrm{Ca}_{3} \mathrm{Al}_{2} \mathrm{Si}_{3} \mathrm{O}_{12}\right)$ (Kong et al. 2017b). The quantified XRD results (Table 3) indicate that BR contained $49.6 \%$ alkaline phases, which originated from the bauxite source, digestion conditions and $\mathrm{CaO}$ addition (Liao et al. 2015). The alkaline phase content in SC decreased from $44.8 \%$ and $45.2 \%$ in the case of BC. This value decreased to $44.2 \%$ and $45.0 \%$ in $\mathrm{SM}$ and BM, respectively. Thus the above biomass transformation investigations exhibited little effect on the change of total alkaline mineral content in bauxite residues. As well, no new characteristic peaks were observed from XRD patterns, suggesting there no new insoluble mineral phases were formed.

Peaks for grossular in XRD patterns were not observed in SC, SM, BC and BM although they existed in BR (Figure 1). It may be concluded that alkaline grossular minerals decompose completely following fermentation of straw and bagasse (as shown in Eq. (1)) (Zhang et al. 2011).

$$
\mathrm{Ca}_{3} \mathrm{Al}_{2} \mathrm{Si}_{3} \mathrm{O}_{12(\mathrm{~s})}+12 \mathrm{H}^{+} \rightarrow 3 \mathrm{Ca}^{2+}+2 \mathrm{Al}^{3+}+3 \mathrm{H}_{4} \mathrm{SiO}_{4}
$$

Peaks for andradite were observed in all bauxite residue samples (BR, SC, SM, $\mathrm{BC}$ and $\mathrm{BM}$ ). This means that andradite was not involved in chemical conversion during the biomass fermentation process, and it was still present in bauxite residues. As shown in Table 3, andradite content increased, which was caused by the dissolution of other minerals in the residue and the reduction in total alkaline minerals (Grafe et al. 2011).

Characteristic peaks for calcite were observed in XRD patterns from both untransformed and biomass transformed bauxite residues. Quantitative analysis indicated that the content of calcite in SC, SM, BC and BM declined following biomass mulching and mixing, but this decrease was not obvious as compared with that of BR. According to previous research, the neutralization reaction between calcite and acid may be presented as Eq. (2), but due to the limitation in solubility, dissolved calcite was relatively small (Genç-Fuhrman et al. 2004). $\mathrm{CO}_{2}$ will be produced during the dissolution process of calcite, and $\mathrm{CO}_{2}$ is also a product during the decomposition of 
biomass (Sharif et al. 2011). When the dissolution process of calcite and the microbial respiration process are carried out simultaneously, it may have a certain inhibitory effect on the dissolution reaction of calcite.

$$
\mathrm{CaCO}_{3(\mathrm{~s})}+2 \mathrm{H}^{+} \rightarrow \mathrm{Ca}^{2+}+\mathrm{CO}_{2(\mathrm{~g})}+\mathrm{H}_{2} \mathrm{O}
$$

Cancrinite exhibited some solubility following straw and bagasse transformation (Eq. (3)) (Zhu et al. 2015), but solubility varied between treatments. Following mixing of straw or bagasse, cancrinite decreased by approximately $6 \%$, but was reduced to $12 \%$ with straw mulching and $15 \%$ with bagasse mulching. This may be attributed to bagasse decomposition products containing more $\mathrm{H}^{+}$, which is favorable to the dissolution of cancrinite.

$$
\mathrm{Na}_{8} \mathrm{Al}_{6} \mathrm{Si}_{6} \mathrm{O}_{24}\left(\mathrm{CO}_{3}\right)\left(\mathrm{H}_{2} \mathrm{O}\right)_{2(\mathrm{~s})}+7 \mathrm{H}^{+}+16 \mathrm{H}_{2} \mathrm{O} \rightarrow 8 \mathrm{Na}^{+}+6 \mathrm{Al}(\mathrm{OH})_{3(\mathrm{~s})}+6 \mathrm{H}_{4} \mathrm{SiO}_{4}+\mathrm{HCO}_{3}^{-}
$$

\subsection{Morphology characteristics}

Na K-edge X-ray absorption near edge structure (XANES) spectra (Figure 2) reveals that un-transformed bauxite residue displays two prominent absorption peaks, b (located at $1076.2 \mathrm{eV}$ ) and e (located at $1080.0 \mathrm{eV})$. The normalized adsorption intensity for peak $\mathrm{b}$ and peak e is 1.02 and 1.23 , respectively. Two prominent absorption peaks, $\mathrm{b}(1076.3 \pm 0.1 \mathrm{eV})$ and peak e $(1080.0 \pm 0.1 \mathrm{eV})$, are also detected in the XANES spectrum of transformed bauxite residues, with normalized intensities of 1.02 and 1.24. Cancrinite was selected as the reference material and the prominent absorption peaks are also located at $1076.2 \mathrm{eV}$ and $1080.0 \mathrm{eV}$, with normalized intensities still at 1.02 and 1.24. Consequently, the main characteristic XANES peaks of the SC, SM, BC, BM and $\mathrm{BR}$ are noticeably consistent with the intensity and position of the absorption peaks for cancrinite. During bauxite residue transformation following addition of different biomass products, cancrinite Na speciation was not significantly changed (Neuville et al. 2004). Therefore, the decomposition process did not change the chemical form of $\mathrm{Na}$ in bauxite residue but caused partial dissolution of cancrinite.

STXM images for $\mathrm{Na}$ in bauxite residue following addition of the various biomass treatments is presented in Figure 3. For the BR, Na elements are strongly and densely distributed in the images with spatial resolution of 30-50 $\mathrm{nm}$. The spatial distribution 
of $\mathrm{Na}$ with straw and bagasse is slightly weakened, but the difference is not obvious. Only the mesoporous spatial distribution of $\mathrm{Na}$ on the fine particles becomes sparse. The regulation of straw and bagasse did not change the Na speciation in bauxite residue.

\subsection{Solution chemistry}

The decrease in $\mathrm{pH}$ is directly related to the forms of alkaline anions $\left(\mathrm{OH}^{-}\right.$, $\mathrm{Al}(\mathrm{OH})_{4}{ }^{-}$and $\mathrm{CO}_{3}{ }^{2-}$ ) in the supernatant of bauxite residue (Table 3) (Gomes et al. 2016). Based on previous studies, alkaline anions may be exhausted by the following reactions (Eqs. (4)-(6))(Kong et al. 2017a). During biomass transformation, the concentration of alkaline anions decreased significantly. Therefore, after biomass transformation, the content of soluble alkali in the bauxite residue decreased, resulting in a decrease in $\mathrm{pH}$. The type of biomass has little difference in the transformation of alkaline anions.

$$
\mathrm{H}^{+}+\mathrm{OH}^{-} \rightarrow \mathrm{H}_{2} \mathrm{O} \quad \text { buffer region: } \mathrm{pH}>10.3
$$

$\mathrm{H}^{+}+\mathrm{Al}(\mathrm{OH})_{4}-\mathrm{Al}(\mathrm{OH})_{3}+\mathrm{H}_{2} \mathrm{O} \quad$ buffer region: down to approximately $\mathrm{pH} 10$

$$
\mathrm{H}^{+}+\mathrm{CO}_{3}{ }^{2-} \rightarrow \mathrm{HCO}_{3}{ }^{-} \quad \text { buffer region: down to approximately } \mathrm{pH} 8.3
$$

Electrical conductivity (EC) of SC, SM, BC and BM supernatants increased significantly (from $1.80 \mathrm{~ms} / \mathrm{cm}$ to $3.65,3.02,3.45$ and 2.72 ), mainly due to the dissolution of soluble cations in bauxite residue (Table 4) (Kong et al. 2017c). The content of soluble $\mathrm{Na}^{+}$for the supernatant transformed by the different biomass products increased significantly (Table 4). With straw and bagasse mulching, $\mathrm{Na}^{+}$ content doubled, but was less than that of bauxite residue treated by mixing. This may be attributed to partial dissolution of soluble alkali in the bauxite residue, such as $\mathrm{NaOH}$ 、 $\mathrm{Na}_{2} \mathrm{CO}_{3}$ 、 $\mathrm{NaHCO}_{3}$ and $\mathrm{NaAl}(\mathrm{OH})_{4}$. Soluble $\mathrm{Ca}^{2+}$ content in the supernatant increased after transformation by biomass (23-40 mg/L) (Table 4). Calcium contained in the bauxite residue dissolved into solution. Most of the grossular in the bauxite residue dissolved into solution, which is confirmed by the disappearance of the characteristic peak of grossular in the XRD pattern. Potassium and $\mathrm{Mg}^{2+}$ in supernatants following treatments was also significantly changed (Table 4). Straw and bagasse contain $\mathrm{K}^{+}$and $\mathrm{Mg}^{2+}$, and their decomposition leads to an increase in the total amount of cations in solution. Due to the different dissolved concentrations of $\mathrm{K}^{+}$and $\mathrm{Mg}^{2+}$ in supernatants from straw and bagasse, it is difficult to determine the specified amount of $\mathrm{K}^{+}$and $\mathrm{Mg}^{2+}$ from the bauxite residue. No soluble Fe was expected to exist in the 
supernatant of BR, but it occured in residues following treatment with the different biomass products. Changes in supernatant soluble Fe concentrations may be due to differences in straw and bagasse Fe contents.

\section{Conclusions}

This work presents a new technology based on biomass to regulate the alkalinity of bauxite residue. When the biomass (straw and bagasse) was added at 10-20\%, the alkaline conversion effect was greatest, with $\mathrm{pH}$ being reduced from 10.26 to 8.56. Furthermore, following transformation of the biomass, alkaline grossular was completely dissolved, with calcite and cancrinite being dissolved to a lesser extent. Straw and bagasse mulching, and straw and bagasse mixing did not change the mesoscale spatial distribution of $\mathrm{Na}^{+}$. Determination of supernatants revealed that basic anions $\left(\mathrm{OH}^{-}, \mathrm{CO}_{3}{ }^{2-}\right.$ and $\left.\mathrm{Al}(\mathrm{OH})_{4}^{-}\right)$were significantly reduced following biomass decomposition. This study provides a potential application for the use of accessible biomass as a green and cost effective alkali modifier for bauxite residue disposal areas.

Acknowledgements This work was supported by National Natural Science Foundation of China (Grant No. 41877511, 41701587).

\section{References}

Babu AG , Reddy MS (2011) Influence of arbuscular mycorrhizal fungi on the growth and nutrient status of bermudagrass grown in alkaline bauxite processing residue. Environ Pollut 159(1):25-29

Barbhuiya SA, Basheer PAM, Clark MW, Rankinb GIB (2011) Effects of seawaterneutralised bauxite refinery residue on properties of concrete. Cement Concrete Comp 33(6):668-679

Burke IT, Peacock CL, Lockwood CL, Stewart DI, Mortimer RJ, Ward MB, Renforth P, Gruiz K, Mayes WM (2013) Behavior of Aluminum, Arsenic, and Vanadium during the Neutralization of Red Mud Leachate by HCl, Gypsum, or Seawater. Environ Sci Technol 47(12):6527-35 
Clark MW, Johnston M, Reichelt-Brushett AJ (2015) Comparison of several different neutralisations to a bauxite refinery residue: Potential effectiveness environmental ameliorants. Appl Geochem 56:1-10

Couperthwaite SJ, Johnstone DW, Millar GJ, Frost RL (2013) Neutralization of Acid Sulfate Solutions Using Bauxite Refinery Residues and Its Derivatives. Ind Eng Chem Res 52(4):1388-1395

Courtney R, Harrington T (2012) Growth and nutrition of Hocus lanatus in bauxite residue amended with combinations of spent mushroom compost and gypsum. Land Degrad Dev 23(2):144-149

Courtney R, Kirwan L (2012) Gypsum amendment of alkaline bauxite residue - Plant available aluminium and implications for grassland restoration. Ecol Eng 42:279282

Courtney RG, Timpson JP (2005) Reclamation of Fine Fraction Bauxite Processing Residue (Red Mud) Amended with Coarse Fraction Residue and Gypsum. Water Air Soil Poll 164(1-4):91-102

David RD, Richard A G (2007) Chemicals from Biomass. Science 318:1249-1250

Genç-Fuhrman H, Tjell JC, McConchie D (2004) Increasing the arsenate adsorption capacity of neutralized red mud (Bauxsol). J Colloid Interf Sci 271(2):313-320.

Gomes HI, Mayes WM, Rogerson M, Stewart DI, Burke IT (2016) Alkaline residues and the environment: a review of impacts, management practices and opportunities. J Clean Prod 112(4):3571-3582

Grafe M, Power G, Klauber C (2011) Bauxite residue issues: III. Alkalinity and associated chemistry. Hydrometallurgy 108(1-2):60-79

Han YS, Ji S, Lee PK, OH C (2017) Bauxite residue neutralization with simultaneous mineral carbonation using atmospheric $\mathrm{CO}_{2}$. J Hazard Mater 326:87-93

Huang L, Li YW, Xue SG, Zhu F, Wu C, Wang QL (2016) Salt composition changes in different stacking ages of bauxite residue. T Nonferr Metal Soc 26: 2433-2439 (In Chinese)

Jones BEH, Haynes RJ, Phillips IR (2012) Addition of an organic amendment and/or residue mud to bauxite residue sand in order to improve its properties as a growth medium. J Environ Manage 95(1):29-38 
Jones G, Joshi G, Clark MW, McConchie DM (2006) Carbon Capture and the Aluminium Industry: Preliminary Studies. Environ Chem 3(4)

Klinke HB, Thomsen AB, Ahring BK (2004) Inhibition of ethanol-producing yeast and bacteria by degradation products produced during pre-treatment of biomass. Appl Microbiol Biotechnol 66: 10-26

Khaitan S, Dzombak DA, Lowry GV (2009) Chemistry of the Acid Neutralization Capacity of Bauxite Residue. Environ Eng Sci 26(5):873-881

Khaitan S, Dzombak DA, Lowry GV (2009) Mechanisms of Neutralization of Bauxite Residue by Carbon Dioxide. J Environ Eng 135(6):433-438

Khaitan S, Dzombak DA, Swallow P, Schmidt P, Fu J, Lowry GV (2010) Field Evaluation of Bauxite Residue Neutralization by Carbon Dioxide, Vegetation, and Organic Amendments. J Environ Eng 136(10):1045-1053

Kirwan LJ, Hartshorn A, Mcmonagle JB, Fleming L, Funnell D (2013) Chemistry of bauxite residue neutralisation and aspects to implementation. Int J Miner Process $119: 40-50$

Klauber C, Gräfe M, Power G (2011) Bauxite residue issues: II. options for residue utilization. Hydrometallurgy 108(1-2):11-32

Kong XF, Guo Y, Xue SG, Hartley W, Wu C, Ye YZ, Cheng QY (2017c) Natural evolution of alkaline characteristics in bauxite residue. J Clean Prod 143:224-230

Kong XF, Jiang XX, Xue SG, Huang L, Hartley W, Wu C, Li XF (2018) Migration and distribution of saline ions in bauxite residue during water leaching. T Nonferr Metal Soc 28(3):534-541

Kong XF, Li M, Xue SG, Hartley W, Chen CR, Wu C, Li XF, Li YW (2017a) Acid transformation of bauxite residue: conversion of its alkaline characteristics. J Hazard Mater 324:382-390

Kong XF, Tian T, Xue SG, Hartley W, Huang LB, Wu C, Li CX (2017b) Development of alkaline electrochemical characteristics demonstrates soil formation in bauxite residue undergoing natural rehabilitation. Land Degrad Dev 29(1):58-67

Li XF, Ye YZ, Xue SG, Jiang J, Wu C, Kong XF, Hartley W, Li YW (2018) Leaching optimization and dissolution behavior of alkaline anions in bauxite residue. $\mathrm{T}$ Nonferr Metal Soc 28(6):1248-1255 
Liao CZ, Zeng L, Shih K (2015) Quantitative X-ray Diffraction (QXRD) analysis for revealing thermal transformations of red mud. Chemosphere 131:171-177

Mayes W M, Younger P L, Jonathan A (2006) Buffering of Alkaline Steel Slag Leachate across a Natural Wetland. Environ Sci Technol 40(4):1237-1243

Menzies NW, Fulton IM, Morrell WJ (2004) Seawater Neutralization of Alkaline Bauxite Residue and Implications for Revegetation. J Environ Qual 33(5):1877-84

Mondala AH (2015) Direct fungal fermentation of lignocellulosic biomass into itaconic, fumaric, and malic acids: current and future prospects. J Ind Microbiol Biotechnol 42:487-506

Neuville DR, Cormier L, Flank AM, Prado RJ, Lagarde P (2004) Na K-edge XANES spectra of minerals and glasses. Eur J Mineral 16:809-816

Patel MA, Ou MS, Harbrucker R, Aldrich HC, Buszko ML, Ingram LO, Shanmugam KT (2006) Isolation and Characterization of Acid-Tolerant, Thermophilic Bacteria for Effective Fermentation of Biomass-Derived Sugars to Lactic Acid. Appl Environ Microb 72: 3228-3235

Power G, Gräfe M, Klauber C (2011) Bauxite residue issues: I. Current management, disposal and storage practices. Hydrometallurgy 108(1-2):33-45

Ren J, Liu JD, Chen J, Liu XL, Li FS, Du P (2017) Effect of ferrous sulfate and nitrohumic acid neutralization on the leaching of metals from a combined bauxite residue. Environ Sci Pollut R 24(10): 9325-9336

Renforth P, Mayes WM, Jarvis AP, Burke IT, Manning DAC, Gruiz K (2012) Contaminant mobility and carbon sequestration downstream of the Ajka (Hungary) red mud spill: The effects of gypsum dosing. Sci Total Environ 421-422:253-259

Sahu RC, Patel RK, Ray BC (2010) Neutralization of red mud using $\mathrm{CO}_{2}$ sequestration cycle. J Hazard Mater 179(1-3):28-34

Santini TC, Fey MV (2015) Fly ash as a permeable cap for tailings management: pedogenesis in bauxite residue tailings. J Soil Sediment 15(3):552-564

Santini TC, Fey MV (2018) From tailings to soil: long-term effects of amendments on progress and trajectory of soil formation and in situ remediation in bauxite residue. J Soil Sediment 18(5):1935-1949

Santini TC, Hinz C, Rate AW, Carterb CM, Gilkesa RJ (2011) In situ neutralisation of 
uncarbonated bauxite residue mud by cross layer leaching with carbonated bauxite residue mud. J Hazard Mater 194:119-127

Sharif MSU, Davis RK, Steele KF, Kim B, Hays PD, Kresse TM, Fazio JA (2011) Surface complexation modeling for predicting solid phase arsenic concentrations in the sediments of the Mississippi River Valley alluvial aquifer, Arkansas, USA. Appl Geochem 26(4):496-504.

Smith P (2009) The processing of high silica bauxites - Review of existing and potential processes. Hydrometallurgy 98(1-2):162-176

Xu BA, Smith P, Wingate C, Silva LD (2010) The effect of calcium and temperature on the transformation of sodalite to cancrinite in Bayer digestion. Hydrometallurgy 105(1-2):75-81

Xue SG, Kong XF, Zhu F, Hartley W, Li XF, Li YW (2016a) Proposal for management and alkalinity transformation of bauxite residue in China. Environ Sci Pollut R 23(13):12822-12834

Xue SG, Li M, Jiang J, Millar GJ, Li CX, Kong XF (2019b) Phosphogypsum stabilization of bauxite residue: Conversion of its alkaline characteristics. J Environ Sci-China 77:1-10

Xue SG, Wu YJ, LI YW, Kong XF, Zhu F, Hartley W, Li XF, Ye YZ (2019a) Industrial wastes applications for alkalinity regulation in bauxite residue: a comprehensive review. J Cent South Univ 26(2):268-288

Xue SG, Zhu F, Kong XF, Wu C, Huang L, Huang N, Hartley W (2016b) A review of the characterization and revegetation of bauxite residues (Red mud). Environ Sci Pollut R 23(2): 1120-1132

Yang Y, Wang XW, Wang MY, Wang HG, Xian PF (2016) Iron recovery from the leached solution of red mud through the application of oxalic acid. Int J Miner Process 157(10):145-151

You F, Zhang LP, Ye J, Huang LB (2019) Microbial decomposition of biomass residues mitigated hydrogeochemical dynamics in strongly alkaline bauxite residues. Sci Total Environ 663:216-226

Zhang R, Zheng SL, Ma SH, Zhang Y (2011) Recovery of alumina and alkali in Bayer red mud by the formation of andradite-grossular hydrogarnet in hydrothermal 
process. J Hazard Mater 189(3):827-835

429 Zhu F, Hou JT, Xue SG, Wu C, Wang QL, Hartley W (2017) Vermicompost and

430 Gypsum Amendments Improve Aggregate Formation in Bauxite Residue. Land $431 \quad$ Degrad Dev 28(7): 2109-2120

432 Zhu F, Zhou JY, Xue SG, Hartley W, Wu C, Guo Y (2016) Aging of bauxite residue in 433 association of regeneration: a comparison of methods to determine aggregate $434 \quad$ stability \& erosion resistance. Ecol Eng 92(3):47-54

435 Zhu XB, Li W, Guan XM (2015) An active dealkalization of red mud with roasting and 436 water leaching. J Hazard Mater 286:85-91 